\title{
PRESENTACIÓN
}

\author{
Soledad Escalante \\ Universidad Antonio Ruiz de Montoya, Lima, Perú \\ ORCID: https://orcid.org/0000-0002-2826-3051 \\ Correspondencia: soledad.escalante@uarm.pe
}

El Perú celebra doscientos ańos de vida independiente y conviene que la comunidad académica se plantee cuestiones importantes acerca de la realización de los ideales de la República. Encontramos lecturas propias, apropiaciones y representaciones de la historia, la temporalidad y la nación que se reconstruyen en la sociedad civil (Vargas Álvarez, 2018). Las profundas desigualdades que nos dividen, la discriminación, la corrupción imperante en diversos círculos políticos constituyen serios obstáculos para construir una comunidad de ciudadanos libres e iguales. La edificación de una República permanece como una promesa incumplida. El presente número de Silex se propone desentrañar la laberíntica tierra de las naciones peruanas, con una perspectiva humanista "sin fronteras" (Usubiaga, 2016, p. 157) que explora las dificultades y los desafíos que se han hecho presentes en nuestra historia nacional.

Después de doscientos años, se erige "una nación que ya no es ni la criolla primigenia ni tampoco la indígena originaria. No es mestiza, es diversa. Es otra 'comunidad', multicultural, podría decirse, la que probablemente Arguedas preferiría” (Pedraglio, 2020, p. 75). El Perú de hoy conserva imágenes y paradigmas con los cuales dialogó a lo largo de su historia y que le permitieron sobrellevar crisis políticas, sanitarias y naturales desde siglos atrás. No es casual la presentación de esta revista, una revisión multidisciplinar de los desafíos y las perspectivas que se presentan a raíz de una celebración identitaria que se cruza con una reconstrucción emocional y vital como consecuencia de la pandemia. Así, se aporta al conocimiento científico social y humanista claves de 
interpretación que permiten responder a la pregunta por el ethos de una nación fragmentada en proceso de reconocimiento, como dice Pablo Quintanilla (2021), ampliando e incorporando a todos los peruanos "al espacio de las razones" (p. 244).

El título de este número, El Bicentenario: desafios y perspectivas, constituye la misma actitud quebrantable de lo acontecido hace doscientos ańos en medio de una nación neófita sumergida en la incertidumbre y la desigualdad. El contexto actual de crisis exige una participación total de la ciudadanía que abrace las distintas afectaciones en búsqueda de una ruptura hacia lo nuevo, que mire este nuevo estado como una posibilidad latente y no como un retorno a viejos males que corroen nuestros cimientos democráticos y de justicia.

Sílex presenta esta edición compuesta de artículos, ensayos y una reseña. Textos con una profunda convicción intelectual y humana para entender no solamente nuestra promesa de república incumplida, sino nuestra esperanza de nación justa. Empezamos con Carlos Fernández Fontenoy que, en su artículo, realiza un análisis comparativo de las características que tuvieron las primeras élites políticas en los inicios de la república peruana con los rasgos de la actual clase política que gobierna el Perú. Seguimos con Gonzalo Gamio que, a partir de nociones como conflicto trágico, oclocracia y agencia política, analiza la segunda vuelta electoral que enfrentó a dos candidatos presidenciales a puertas del bicentenario. Y si hablamos de cambios, conviene revisar el artículo de Rosa Elvira Vargas, que reflexiona sobre las posibles causas de fragmentación actual que vive nuestra nación, con el fin de proporcionar algunos lineamientos - gracias a la teoría política de Aristóteles- para la reforma del régimen vigente.

Siguiendo con la primera sección de artículos, Laura Balbuena Gonzales observa críticamente las diferentes etapas de acceso al voto femenino y su representación parlamentaria, teniendo como mirada una perspectiva interseccional. Asimismo, Milagros Varela, a modo de espía, busca en la historia de los primeros años republicanos las causas de los desafíos que enfrenta actualmente el Perú para superar las 
desigualdades económicas y sociales, eliminar la discriminación y acabar con la corrupción. Y cerrando esta sección, Rolando Iberico reflexiona sobre la trayectoria de la Iglesia católica en los últimos doscientos años en el Perú desde una clave histórico-eclesiológica, que abre desafíos para nuevos roles públicos de la Iglesia en el Perú del siglo xxı.

Ingresando a la sección de ensayos, tenemos miradas amplias como la del grupo de investigación "Tradición, escritura y pensamiento crítico en la obra de Manuel González Prada" que nos ofrece una lectura interdisciplinar sobre la crítica a la clase dirigente, la relación entre Revolución francesa y el bicentenario en el Perú, el imperativo cristiano y la creación del público moderno. También, encontramos a Gabriel Moreno que analiza las dinámicas de constitución de las identidades anticomunistas en la segunda vuelta electoral del 2021 en el Perú, que problematiza esta particular dinámica de significación afectiva. Y, por último, Christian Egoavil analiza las relaciones intelectuales entre los europeos y los americanos a partir de un texto de Juan Vásquez de Acuña en plena revolución científica del siglo xviI.

Cerramos este número con Ricardo Falla que nos ofrece una reseña de El Experimento democrático. Reflexiones sobre teoría política y ética civica de Gonzalo Gamio, en la que muestra una teoría sobre el deber ser intelectual cuando esta práctica se ubica ante la complejidad del mundo político y sus múltiples problemas.

Para finalizar, las complejidades son tierras fértiles para abrir caminos en donde sembremos miradas críticas y nuevas posibilidades de habitar y comprender nuestra realidad. Este tiempo complejo no es casualidad, como tampoco lo es la perspectiva humanista que pretende ofrecer la revista a sus lectores el día de hoy.

\section{La directora}




\section{Bibliografía}

Pedraglio, S. (2021). A doscientos años. Las llaves de ingreso a la nación peruana. Revista Psicoanálisis, 26.

Quintanilla, P. (2021). El diálogo público y la fuerza de las razones. En 2021: las elecciones y el bicentenario ¿Oportunidades desperdiciadas o aprovechadas? (1.a ed., pp. 239-244). Fondo Editorial PUCP. https://repositorio.pucp.edu.pe/index/bitstream /handle/123456789/175748/2021_Las_elecciones_y_el_ bicentenario.pdf?sequence $=6 \&$ isAllowed $=y$

Usubiaga, V. (2016). Estados del arte. Puestas en escena de construcciones históricas e imaginarias durante el Bicentenario en Argentina. Cuadernos De Literatura, 20(40), 155-180. https:// doi.org/10.11144/Javeriana.cl20-40.eape

Vargas Álvarez, S. (2018). Después del bicentenario: políticas de la conmemoración, temporalidad y nación: Colombia y México, 2010. Editorial Universidad del Rosario. 